\title{
Letter to Editor
}

\section{Making Meaning of Frightening NDEs}

To the Editor:

Nancy Evans Bush quoted John Sanford in her recent article entitled "Afterward: Making Meaning After a Frightening Near-Death Experience," to remind us that Christianity is "the most psychological of all religions because of [its] emphasis on the inner development of the individual and the important role which it assigns to the ego as the bearer of consciousness" (Bush, 2002, p. 114).

We forget that fact, as near-death experiencers and researchers, in our quest to make "meaning," to interpret the near-death phenomenon from a grander view, to assert spirituality over religiosity, to "free" ourselves from the limits of any dogma that might have constrained us in the past. Bush, as an experiencer of an unpleasant near-death episode, as President Emeritus of the International Association for Near-Death Studies (IANDS), and from her extensive background in Christian studies and pastoral counseling, brought to the table a fresh and remarkably insightful viewpoint-especially as concerns that which is frightening or confusing to us.

Her article was masterful, the best interpretative piece I have ever read, book or article, on the near-death phenomenon and the meanings we may give it. I sincerely hope that this work was a mere precursor to a book she will pen on the subject. I have known Bush since she was first hired to work for IANDS, and have found her to be a deep and thoughtful individual, always thorough and always inviting us to rethink our ideas and commentary.

On page 111 of her article, she pointed a finger of suspicion at my discovery of four types of near-death states and how I described them, objecting most to the subtle, psychological profile I detailed for each, and especially as concerns unpleasant and/or hell-like episodes. She quoted me as saying this type "is usually experienced by those who seem to have deeply suppressed or repressed guilts, fears, and angers, and/or those who expect some kind of punishment or accountability after death" (Atwater, 1992, p. 156). Her objection was that people who 
report radiantly wondrous accounts have self-described guilts, fears, and angers, too. And she was absolutely correct.

I have no argument here. But I would remind Bush that all my research findings are based on original fieldwork. My role has always been that of observer/investigator, not scholar or meaning-maker (global or otherwise). Yes, people who claimed to have visited heaven dealt with the unfinished business of their lives during and afterward, as did just about everyone else, irrespective of scenario type. What I witnessed with experiencers consistently, though, was that the predominant issues in their lives at the time were what appeared most to infuse the imagery and message of their near-death episode. What I discovered is exactly as declared. I cannot change what I found because it does not feel right or seems a cop-out of some kind or an assumption hastily made. Like it or not, there is a link between whatever exists within our deepest selves and what outpictures during a near-death episode. But that link is only an initial one. As Bush well knows, there is far more to the near-death phenomenon than the status of our attitudes and beliefs. I bow to her expertise in this regard, as she continues to uncover gems from the vast world of religious and spiritual traditions and what that might tell us about the near-death phenomenon, its aftereffects and implications.

\section{References}

Atwater, P. M. H. (1992). Is there a hell? Surprising observations about the near-death experience. Journal of Near-Death Studies, 10, 149-160.

Bush, N. E. (2002). Afterward: Making meaning after a frightening near-death experience. Journal of Near-Death Studies, 21, 99-133.

P. M. H. Atwater P.O. Box 7691

Charlottesville, VA 22906-7691 e-mail: atwater@cinemind.com 